\title{
Effect of deferred grazing during late spring and summer on pasture productivity in Waikato and Bay of Plenty hill country
}

\author{
Katherine N. TOZER ${ }^{1 *}$, Karin MÜLLER ${ }^{2}$, Tony CRAVEN ${ }^{1}$, Ian TARBOTTON ${ }^{3}$, \\ Allen COSTER $^{4}$, Rick BURKE ${ }^{5}$, Jon SHERLOCK ${ }^{6}$ and Catherine CAMERON ${ }^{1}$ \\ ${ }^{1}$ AgResearch, Private Bag 3123, Hamilton 3214, New Zealand \\ ${ }^{2}$ Plant \& Food Research, Private Bag 3230, Hamilton 3240, New Zealand \\ ${ }^{3}$ Ballance Agri-Nutrients Ltd, Private Bag 12-503, Tauranga 3143, New Zealand \\ ${ }^{4}$ Mataiwhetu Station, 29 Thorn Road, Lower Kaimai 3171, New Zealand \\ ${ }^{5}$ Pukekauri Farms, 181 Lund Road, Katikati 3178, New Zealand \\ ${ }^{6}$ Otorohaea Ltd, 369 Otorohaea Trig Road, Ngaruawahia 3794, New Zealand \\ *Corresponding author: Katherine.tozer@agresearch.co.nz
}

\begin{abstract}
Deferred grazing is a commonly used tool to manage feed surpluses. The effect of deferred grazing on pasture nutritive value and productivity was quantified in a split-paddock trial on three hill country farms in Waikato and Bay of Plenty from October 2018 until May 2020. Livestock were excluded from the deferred pasture between mid-October 2018 and March 2019. Thereafter, both treatments were rotationally grazed in common with cattle or sheep depending on the farm. Total annual dry matter production was $15 \%$ greater in the deferred than grazed treatment for the 12 months after deferring ( 8.9 vs 7.7 t DM/ha, $\mathrm{P}<0.05$ ). Metabolisable energy (ME) values at the end of the deferred period were lower in the deferred than grazed treatment $(\mathrm{P}<0.01)$ but similar in both treatments thereafter. The content of legumes other than white clover (Trifolium repens) was higher in deferred than grazed pastures in spring 2019 on one of the farms (treatment $\times$ farm interaction $\mathrm{P}<0.05$ ). Ground cover of perennial ryegrass was greater and the area of bare ground smaller, in the deferred than grazed treatment on three of five occasions from after the beginning of the deferred period until up to 8 months after deferring $(\mathrm{P}<0.05)$. There was no difference between treatments in decomposition and stabilisation of organic matter $(\mathrm{P}>0.05)$. The topsoil water content was higher in the deferred than grazed treatment for 12 months after deferring. In comparison to regular grazing between October and March, deferred pastures provided drought feed in autumn 2019. Pasture productivity was increased after the deferred period without negative impacts on ME.
\end{abstract}

Keywords: summer fallow, grazing management, hill country, pasture management

An Agricultural Practices article reports on applied work: e.g. practical onfarm demonstration over multiple years of previously published scientific research that describes the situation before and after the application of a new approach.

\section{Background}

Hill country farmers throughout New Zealand are faced with climatic and environmental pressures. Climatic extremes make it difficult to provide a predictable feed supply throughout the year, particularly given the recent and extensive summer droughts in the upper North Island. These pressures have led to declines in pasture quality and persistence of desirable species such as perennial ryegrass (Lolium perenne L.) and shortages of feed. Concerns regarding the effect of nutrient runoff from hill country on water quality also need to be addressed (Gordon et al. 2010), for example, through minimising the presence of bare ground and improving water infiltration into the soil.

Deferred grazing is a common pasture management practice used to control surplus spring pasture by dropping paddocks out of the grazing round for an extended period (e.g. Suckling 1959). This practice increases grazing pressure on the paddocks that have not been deferred so that feed supply better matches livestock demand, and pasture quality is improved on those remaining paddocks. In New Zealand hill country, Sheath and Boom (1985) and Sheath et al. (1984) investigated the effect of hard or lax grazing in spring followed by combinations of spelling (deferring) or grazing in summer and autumn on hill-country pastures and soils. However, in this study, we have focused on a deferred period (i.e. no grazing) from mid-spring until the end of summer / early autumn due to the benefits for tillering of ryegrass (Matthew et al. 1991; Kemp \& Dowling 2000). Increases in herbage production and ground cover in deferred pastures after a spring-summer deferred period have been documented in Australian hill country (Nie \& Zollinger 2012; Nie et al. 2015). To the best of our knowledge, there are no published studies that have quantified the effect of deferring from mid-spring until the end of summer on nutritive values or ground cover in New Zealand pastures.

Three farmers from the Beef + Lamb New Zealand mid-northern North Island Farmer Council have used 
deferred grazing on $10-20 \%$ of their farm each year, depending on feed availability, for the last 10-15 years. Benefits from their perspective include rejuvenation of the deferred pasture (i.e. increased dry matter production, and more ryegrass and ground cover) without negative impacts on pasture quality after the deferred period. Therefore, a trial was established on two farms in Bay of Plenty and one in Waikato to quantify the effect of deferred grazing on pasture performance over 20 months, and in particular to provide data on the effect of deferred grazing from mid-spring to late summer / early autumn on subsequent pasture quality and ground cover. The project team decided that the most critical indicators of success were herbage accumulation (based on assessment methods typically used by farmers), botanical composition, nutritive value, ground cover and soil microbial activity. The latter reflects soil microbiological processes which are susceptible to changes in soil environmental conditions and more responsive than physical or chemical soil parameters (Cardoso et al. 2013). Based on the existing scientific literature, we tested the hypotheses that:

- deferring the grazing of a pasture would result in increased herbage production and abundance of perennial ryegrass after the deferred period without negative effect on nutritive values when compared to standard rotational grazing; and

- deferred grazing changes the topsoil microclimate (temperature, soil moisture), which directly affects soil microbial activity and thereby nutrient cycling and mineralisation of organic matter.

Yorkshire fog (Holcus lanatus L.) was monitored separately as the farmers considered it to be one of the most prevalent weedy grasses.

\section{Approach}

The aim of an Agricultural Practices paper is to report on a practical on-farm demonstration over multiple years of previously published scientific research showing the situation before and after the application of the new approach.

\section{Site characteristics}

Sites were established in two paddocks on each of three sheep and beef hill country farms near Pukemiro (northwestern Waikato), Lower Kaimai (Bay of Plenty) and Katikati (Bay of Plenty). Rainfall was below average for over half of the study period and especially during the summers of 2018-2019 and 2019-2020 and autumn 2020, particularly at the Pukemiro site (Additional online file: Figure A1).

\section{Baseline situation}

Six replicate paddocks were selected based on their homogeneity and road access. They varied in topography and soil characteristics (Table 1). Herbage accumulation from 1 September until mid-October when treatments were applied was similar (2250 and $2150 \mathrm{~kg} \mathrm{DM} / \mathrm{ha}$ in the grazed and deferred treatments respectively $(\mathrm{P}>0.05))$.

\section{Grazing management changes}

Each paddock was split into two sections ('plots') with an electric fence to which the grazed or deferred treatments were randomly assigned. The grazed treatment comprised the standard rotational grazing practices on each farm (Table 2). Livestock were excluded from the deferred areas starting from between 23 September and 23 October 2018 until between 18 February and 20 March 2019 depending on the paddock, after perennial ryegrass had flowered and set seed. Thereafter, both treatments were grazed in common by beef cattle or sheep at rates of 8-14 SU/ha depending on the paddock, farm and year. The Scotties paddock at the Kaimai site was eliminated from the trial from spring 2019 due to the farmer needing to use the paddock for lambing.

Herbage mass was assessed in each plot before and after grazing using a capacitance probe (GrassMaster Pro; Novel Ways Ltd, Taupo, NZ) at Pukemiro and Kaimai and a rising plate meter (RPM, EC 10 Electronic Platemeter; Jenquip, Feilding, NZ) at Katikati. There were 50 randomly positioned placements of the RPM/ probe in each plot, except at Kaimai, where there were 30 placements within each plot. Herbage produced between grazings (i.e. pre-grazing - previous postgrazing) was summed to estimate herbage production.

All other pasture assessments were completed for both treatments within 48 hours of grazing the control treatment. There were two assessments in 2018: midspring (October) prior to livestock being excluded from the deferred treatment and early summer (December); four in 2019: late summer (February), late autumn (May), spring (October) and early summer (December); and two in 2020: late summer (February) and late autumn (May).

Estimates of pasture nutritive values (metabolisable energy (ME), crude protein (CP) and neutral detergent fibre (NDF)) of the feed-on-offer, were derived by cutting 30 snip samples to $1 \mathrm{~cm}$ above the soil surface which were bulked within each plot using the method described by Litherland et al. (2002). This method has been used to estimate the botanical composition of the herbage consumed by livestock (Lantinga et al. 2004). Approximately $100 \mathrm{~g}$ of herbage was subsampled using the quartering method (Cayley \& Bird 1996), snap frozen in liquid nitrogen, stored at $-20^{\circ} \mathrm{C}$, freeze dried, ground to a fine powder with particle sizes of less than $1 \mathrm{~mm}$ (Cyclone sample mill; UDY Corp., Fort Collins, CO, USA) and analysed by a commercial analytical laboratory (Hill Laboratories, Hamilton) using near-infrared spectroscopy (NIRS) 
analysis (Corson et al. 1999). The remainder of the herbage was transported chilled and stored at $4^{\circ} \mathrm{C}$ for up to one week before botanical composition analysis. This involved dissecting the herbage into perennial ryegrass, Yorkshire fog, other grasses, white clover
(Trifolium repens $\mathrm{L}$.), other legumes, weedy broadleaf species and dead vegetation. Components were oven dried at $96^{\circ} \mathrm{C}$ to a constant weight and weighed to derive an estimate of their percentage contribution to total dry matter.

Table 1 Characteristics (latitude, longitude, slope angle, soil characteristics) of the trial plots and the paddock size at three sites - Pukemiro, Kaimai, and Katikati.

\begin{tabular}{|c|c|c|c|c|c|c|}
\hline \multirow{2}{*}{$\begin{array}{l}\text { Characteristic } \\
\text { Latitude } \\
\text { Longitude } \\
\text { Paddock name }\end{array}$} & \multicolumn{2}{|c|}{$\begin{array}{c}\text { Pukemiro } \\
37^{\circ} 38^{\prime} 46^{\prime \prime} \mathrm{S} \\
174^{\circ} 59^{\prime} 38^{\prime \prime} \mathrm{E}\end{array}$} & \multicolumn{2}{|c|}{$\begin{array}{c}\text { Kaimai } \\
37^{\circ} 47^{\prime} 42 \text { ' S } \\
176^{\circ} 02^{\prime} 13^{\prime \prime} \text { E }\end{array}$} & \multicolumn{2}{|c|}{$\begin{array}{c}\text { Katikati } \\
37^{\circ} 36^{\prime} 24^{\prime \prime} \mathrm{S} \\
175^{\circ} 53^{\prime} 44^{\prime \prime} \mathrm{E}\end{array}$} \\
\hline & Gentle & Steep & Woolshed & Scotties & Top Hill & Crashes \\
\hline Paddock size (ha) & 1.7 & 3.6 & 5.6 & 3.0 & 1.8 & 2.1 \\
\hline Slope angle $\left({ }^{\circ}\right)$ & 7 & 29 & 23 & 21 & 13 & 20 \\
\hline Aspect & SW & NW & SE & SE & SE & NW \\
\hline Soil type & $\begin{array}{l}\text { Dunmore } \\
\text { silt loam }\end{array}$ & $\begin{array}{c}\text { Waingaro } \\
\text { steepland soil }\end{array}$ & $\begin{array}{l}\text { Kaharoa / } \\
\text { Waihi ash }\end{array}$ & $\begin{array}{l}\text { Kaharoa / } \\
\text { Waihi ash }\end{array}$ & $\begin{array}{l}\text { Waihi } \\
\text { ash }\end{array}$ & $\begin{array}{l}\text { Waihi } \\
\text { ash }\end{array}$ \\
\hline $\mathrm{pH}\left(\mathrm{H}_{2} \mathrm{O}\right)^{\mathrm{a}}$ & 5.5 & 5.3 & 5.5 & 5.7 & 5.9 & 5.6 \\
\hline Olsen phosphate $\left(\mu \mathrm{g} \mathrm{mL}^{-1}\right)$ & 38 & 37 & 15 & 10 & 8 & 16 \\
\hline Potassium (MAF QT) ${ }^{b}$ & 10 & 18 & 5 & 4 & 5 & 7 \\
\hline Calcium (MAF QT) & 10 & 10 & 3 & 4 & 9 & 7 \\
\hline Magnesium (MAF QT) & 38 & 74 & 11 & 9 & 15 & 18 \\
\hline Sodium (MAF QT) & 7 & 10 & 3 & 4 & 5 & 5 \\
\hline Organic matter (\%) & 21 & 12 & 18 & 17 & 16 & 16 \\
\hline Total carbon (\%) & 12 & 7 & 10 & 10 & 9 & 9 \\
\hline
\end{tabular}

a soil tested November 2018; ${ }^{\mathrm{b}}$ MAF QT (Quick Test) units (Cornforth 1980; Cornforth \& Sinclair 1984).

Table 2 Pasture management details for the paddocks at the three trial sites - Pukemiro, Kaimai, and Katikati.

\begin{tabular}{|c|c|c|c|c|c|c|}
\hline \multirow{2}{*}{$\begin{array}{l}\text { Farm name } \\
\text { Main livestock class grazing trial paddocks }\end{array}$} & \multicolumn{2}{|c|}{ Pukemiro } & \multicolumn{2}{|c|}{ Kaimai } & \multicolumn{2}{|c|}{ Katikati } \\
\hline & Heifers & & Heifers / ewes & & Heifers & \\
\hline Method used to assess herbage mass & Probe & & Probe & & Plate meter & \\
\hline Paddock name & Gentle & Steep & Woolshed & Scotties & Top Hill & Crashes \\
\hline Beginning of deferred period 2018 & 23 Sep & 3 Oct & 23 Oct & 23 Oct & 19 Oct & $23 \mathrm{Oct}$ \\
\hline End of deferred period 2019 & $18 \mathrm{Feb}$ & $20 \mathrm{Feb}$ & 6 Mar & 12 Mar & $20 \mathrm{Mar}$ & $8 \mathrm{Mar}$ \\
\hline Length of deferred period (weeks) & 21 & 20 & 19 & 20 & 22 & 19 \\
\hline Stock used to graze off deferred pasture & $\mathrm{R} 2$ heifers & R1 heifers & ewes & ewes & R2 heifers & R2 heifers \\
\hline Number of grazings $2018\left(\right.$ Oct-Dec) ${ }^{a}$ & $3(1)$ & $3(1)$ & $1(1)$ & $1(1)$ & $2(1)$ & $2(1)$ \\
\hline $2019\left(\right.$ Jan-Dec) ${ }^{a}$ & $8(8)$ & $6(6)$ & $6(5)$ & $5(5)^{b}$ & $10(8)$ & $12(11)$ \\
\hline 2020 (Jan-May) $^{a}$ & $2(2)$ & $2(2)$ & $4(4)$ & - & $2(2)$ & $4(4)$ \\
\hline Pre-grazing herbage mass end deferred $(\mathrm{kg} \mathrm{DM} / \mathrm{ha})^{\mathrm{c}}$ & 3800 & 4600 & 4300 & 4600 & 3600 & 4000 \\
\hline Post-grazing herbage mass end deferred $(\mathrm{kg} \mathrm{DM} / \mathrm{ha})^{\mathrm{c}}$ & c 900 & 1700 & 2200 & 2500 & 1200 & 2000 \\
\hline Average pre-grazing herbage mass $(\mathrm{kg} \mathrm{DM} / \mathrm{ha})^{d}$ & 2200 & 1900 & 2600 & 2200 & 2300 & 2100 \\
\hline Average post-grazing herbage mass $(\mathrm{kg} \mathrm{DM} / \mathrm{ha})^{d}$ & 1300 & 1300 & 1500 & 1200 & 1300 & 1400 \\
\hline Length of sampling transect $(\mathrm{m})$ & 100 & 50 & 40 & 30 & 60 & 100 \\
\hline
\end{tabular}

${ }^{a}$ Number of grazings for the grazed treatment (and deferred treatment in parenthesis);

${ }^{b}$ Measurements were discontinued in Scotties from 16 August 2019 when the paddock was set-stocked for lambing;

c in the deferred treatment;

${ }^{d}$ excluding data from the grazing at the end of the deferred period in the deferred treatment. 
Ground cover of vegetation was visually assessed in four $2 \mathrm{~m} \times 2 \mathrm{~m}$ quadrats randomly positioned in each plot, except for the Pukemiro steep paddock, where ground cover was assessed in five quadrats in each plot. Assessments were conducted by the same operator at all sites on all occasions using the following vegetation categories, which included both living and senescent tissue: perennial ryegrass, Yorkshire fog, other grasses, total legumes, legumes other than white clover, broadleaf weedy species and bare ground. Ground cover data provided information on the spatial and temporal distribution of plant types and their recovery after drought, while herbage sampling provided an indication of the herbage consumed by livestock.

To assess microbial decomposition capacity in the topsoil, we employed the widely used tea bag index (TBI; Keuskamp et al. 2013) (http://www. teatime4science.org). One bag each of green (Camellia sinensis (L.) Kuntze) and rooibos (Aspalathus linearis (Burm.f.) R.Dahlgren) tea were buried side by side in the soil at $5 \mathrm{~cm}$ depth at three random positions in each plot in mid-November. Two types of tea were used with differing rates of decomposition ability (rooibos leaves decompose more slowly than green tea leaves). Weight loss was determined over the burial period of 116 , 117 and 120 days at Kaimai, Katikati and Pukemiro, respectively. These data were used to derive the two parameters of the two-phase litter decomposition curve (Wider \& Lang 1982), i.e. the decomposition rate constant (which is characteristic of fast decomposition of labile compounds) and the litter stabilisation factor (which reflects the slower decomposition of more recalcitrant material) (Keuskamp et al. 2013). These parameters are influenced by responses of the microbial organisms to differences in environmental conditions, such as soil temperature and moisture (Davidson \& Janssens 2006; Keuskamp et al. 2013; Xiao et al. 2014).

Topsoil temperature beside one pair of teabags in each plot was logged in 90-min intervals from 22 November 2018 to 18 March 2019. Fifteen $1.5-\mathrm{cm}$ diameter soil cores were collected to a depth of $7.5 \mathrm{~cm}$ from random locations within the plot and bulked on each sampling occasion. The initial soil samples were sent to a commercial analytical laboratory (Hill Laboratories, Hamilton) for analysis of the soil nutrient status in October 2018 (Table 1). Thereafter, on each sampling occasion, soil samples were weighed, oven dried at $105^{\circ} \mathrm{C}$ for $48 \mathrm{~h}$ and re-weighed to estimate the gravimetric soil moisture content.

\section{Statistical analyses}

Data were analysed using Genstat, 19th edition (VSN International 2018) by REML with treatment (deferred or grazed) as the fixed effect and farm and paddock within farm as random effects. For ground-cover data, farm, treatment and their interaction were included as fixed effects and paddock within farm as the random effect.

A repeated measures analysis fitting farm, treatment, time (before deferred, end deferred and autumn postdeferred) and their interactions as fixed effects and paddock within farm as random effect was performed for soil moisture data for summer to autumn 2018/19, and another analysis with spring, early summer and late summer as the times for the repeated measures analysis.

\section{Results}

\section{Pasture production and quality}

There was no significant difference between treatments in any of the seasons in herbage production although after the deferred period, there was a consistent pattern of greater herbage production in the deferred than grazed treatment $(\mathrm{P}>0.05$; Additional online file, Figure A2). These differences led to accumulated dry matter production being significantly greater (approximately $15 \%)$ in the deferred than grazed treatments for 9 months (autumn - spring 2019, 7500 vs $6400 \mathrm{~kg} \mathrm{DM/}$ ha) and 12 months (autumn 2019 - summer 2019-20, 8900 vs $7700 \mathrm{~kg} \mathrm{DM} / \mathrm{ha})$ after deferring $(\mathrm{P}<0.05)$.

There was no difference between grazed and deferred treatments in nutritive values before the deferred treatment was applied (Figure 2). Deferring grazing negatively affected all three pasture nutritive value parameters (ME, CP and NDF) relative to the grazed control during the trial (Figure 2). Deferred paddocks in December 2018 had lower ME $(\mathrm{P}<0.05)$ and $\mathrm{CP}$ and higher NDF $(\mathrm{P}<0.05)$ and in February 2019 lower $\mathrm{ME}(\mathrm{P}=0.001)$ (Figures 2a-c). Of the three parameters analysed, only NDF differed significantly after the deferred period; in May 2019, it was higher in the deferred than grazed treatment (50 vs $45 \%$, $\mathrm{P}<0.05$ ).

\section{Pasture composition}

There was no effect of treatment on the percentage in total dry matter of ryegrass, other grass species, white clover, total legume or broadleaf species during the study ( $P>0.05$, Figures $3 a, b, c$ and $d)$. In the autumn after deferring, legumes (mainly red clover (Trifolium pratense L.)) other than white clover were more prevalent in the deferred than grazed treatment at Katikati ( 6 vs $2 \%$, interaction $\mathrm{P}<0.05)$ but there was no difference between treatments at the other sites where legumes other than white clover comprised less than $1 \%$ of total dry matter. The percentage of dead vegetation was greater in the deferred than grazed treatment in December 2018 (10 vs 9\%, $\mathrm{P}<0.05$, Figure $3 \mathrm{e}$ ) as was the percentage of Yorkshire fog (17 vs $12 \% \pm 1.6 \%$, $\mathrm{P}<0.05$; data not shown). However, after the deferred period there was no difference between treatments in 


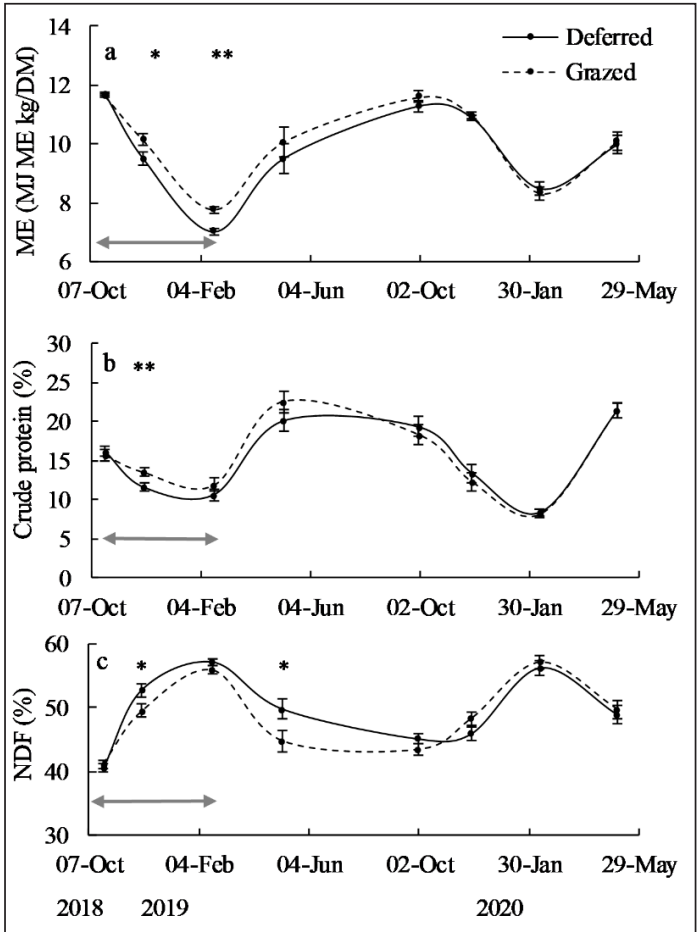

Figure 2 Metabolisable energy, crude protein content (\%) and NDF (neutral detergent fibre) content of deferred and grazed pastures averaged over 6 paddocks on 3 farms in Waikato / Bay of Plenty. Error bars represent the standard error of difference. The arrow denotes the grazing exclusion period in the deferred treatment. Asterisks denote when differences between treatments are significant: ${ }^{*} \mathrm{P}<0.05,{ }^{* *} \mathrm{P}<0.01$.

the percentage of Yorkshire fog until February 2020, when it was lower in the deferred than grazed treatment ( 2 vs $6 \% \pm 1.4, \mathrm{P}<0.05$; data not shown).

\section{Ground cover}

Greater differences between treatments were detected using ground cover than herbage sampling. There was no difference between treatments in perennial ryegrass ground cover in October 2018 or October $2019(\mathrm{P}>0.05)$ but it was higher in the deferred than grazed treatment by $50 \%$ in December $2018(\mathrm{P}<0.01), 30 \%$ in May $2019(\mathrm{P}<0.05)$ and 50\% in December $2019(\mathrm{P}=0.01$, Figure 3f). 'Other grass species' were predominantly Yorkshire fog, browntop (Agrosits capillaris L.) and sweet vernal (Anthoxanthum odoratum L.). These dominated the sward particularly in February 2019, when their ground cover was higher in the deferred than grazed treatment $(\mathrm{P}<0.05$, Figure $3 \mathrm{~g})$. This was mainly due to the higher cover of Yorkshire fog in the deferred than grazed treatment in February 2019 (27 vs $11 \% \pm 6 \%, \mathrm{P}<0.05)$. However, at all other times it was similar in both treatments and remained below $10 \%$ of total ground cover $(\mathrm{P}>0.05)$.

Total legume ground cover was lower in the deferred than grazed treatment in December $2018(\mathrm{P}<0.01$, Figure $3 \mathrm{~h})$ but similar in both treatments thereafter $(\mathrm{P}>0.05)$. There was no difference between the deferred and grazed treatments in ground cover of weedy broadleaf species $(\mathrm{P}>0.05)$, which remained below $12 \%$ of total ground cover (Figure 3i), except in December 2019. At that time, ground cover of broadleaf species was greater in the grazed than deferred treatment at Katikati (21 vs $8 \pm 1 \%$ ) but was similar in both treatments at Kaimai (averaging $1 \pm 1 \%$ ) and Pukemiro (averaging $9 \pm 1 \%$, $\mathrm{P}<0.05$ ). This difference at Katikati was largely driven by a reduction in the ground cover of Californian thistle (Cirsium arvense L.) in response to deferred grazing. There was more bare ground in the grazed than deferred treatment in December $2018(\mathrm{P}<0.05)$, February 2019 $(\mathrm{P}=0.001)$ and May $2019(\mathrm{P}<0.05)$ (Figure 3j).

\section{Microbial activity and microclimate}

There were no differences between the two treatments in the microbial decomposition rate factor $(0.0147 \pm$ 0.0019 and $0.0151 \pm 0.0015$ for deferred and grazed treatment, respectively) or stabilisation factors $(0.198$ \pm 0.014 and $0.195 \pm 0.014$ for deferred and grazed treatments, respectively).

Temperature data loggers were faulty or could not be retrieved from the Pukemiro farm and from one paddock on the Kaimai farm. For the remaining three paddocks located on two farms, the average topsoil temperature was significantly lower in the deferred $\left(20.1^{\circ} \mathrm{C} \pm\right.$ $\left.0.04^{\circ} \mathrm{C}\right)$ than grazed $\left(21.4^{\circ} \mathrm{C} \pm 0.06^{\circ} \mathrm{C}\right)$ treatment $(\mathrm{P}<0.05)$. The maximum topsoil temperatures observed in the three grazed plots were 30,32 and $27^{\circ} \mathrm{C}$, which were consistently higher than those in their adjacent deferred plots $\left(27,26\right.$ and $24^{\circ} \mathrm{C}$ respectively).

Water content at a depth of $0-7.5 \mathrm{~cm}$ was similar in both treatments in December 2018 but soil moisture was $24 \%$ higher in the deferred than grazed treatment at the end of the deferred period in February $2019(\mathrm{P}<0.01)$ during the drought (Additional online file, Figure A1) and 10\% higher in December $2019(\mathrm{P}<0.01)$ (Figure 4).

Based on a repeated measures analyses, there was a higher soil water content at a depth of $0-7.5 \mathrm{~cm}$ in the deferred than grazed treatment when averaged over summer 2018-2019 and autumn 2019 (28 vs. 25\%, $\mathrm{P}<0.01$ ), and spring 2019 and summer 2019-2020, 33 vs $31 \%, \mathrm{P}<0.001)$.

\section{Discussion}

\section{Pasture performance}

Deferred pastures produced approximately $15 \%$ more dry matter than grazed pastures in the 9-12 months after deferring, with negligible impact on nutritive 

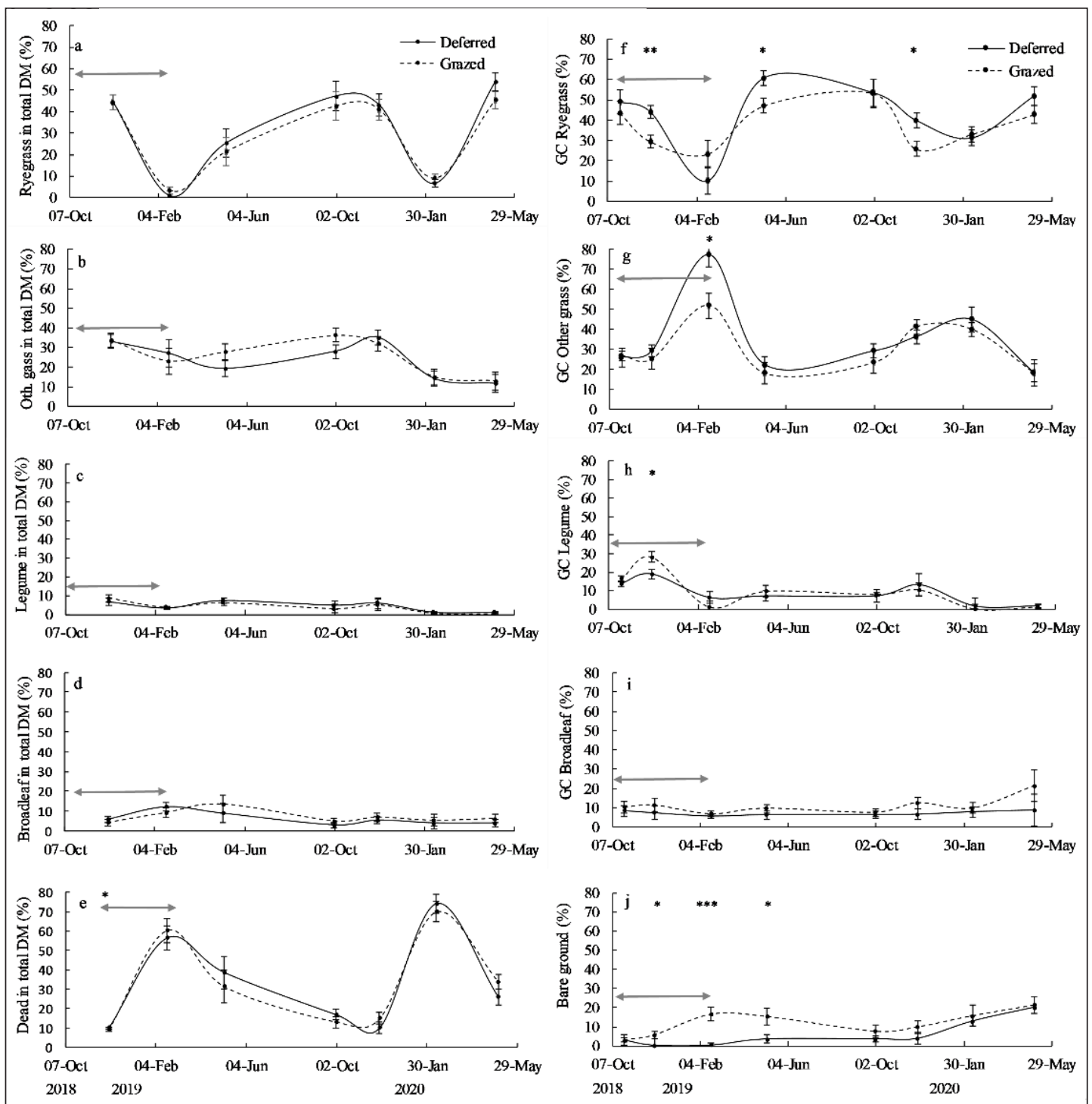

Figure 3 Percentage in total dry matter of (a): perennial ryegrass, (b): Yorkshire fog and other grasses combined; (c): legume; (d): broadleaf; and (e) dead vegetation; and percentage ground cover (GC) of (f): perennial ryegrass, (g): Yorkshire fog and other grasses combined; (h): legume, (i): broadleaf; and (j) bare ground of deferred and grazed pastures averaged over 6 paddocks on 3 farms in Waikato / Bay of Plenty. Error bars represent the standard error of the difference. The arrow denotes the grazing exclusion period in the deferred treatment. Asterisks denote when differences between treatments are significant: ${ }^{*} \mathrm{P}<0.05,{ }^{* *} \mathrm{P}<0.01,{ }^{* * *} \mathrm{P}<0.001$.

value other than during the deferred period. Impacts lasted for up to 12 months after deferring, depending on the variable measured. Although methods used to assess dry matter varied between farms (plate vs probe, Table 1) and the number of farm replicates was low, the dry matter production benefits from deferring were statistically significant.

Deferred pastures also had a higher ground cover of desirable species, such as ryegrass, after the deferred period. This was most likely due to ryegrass reseeding
(L'Huillier \& Aislabie 1988) and/or an increase in tiller densities of existing plants (Waller et al. 2003). Legume content remained $<10 \%$ of total dry matter in all pastures.

There was a large decline in herbage nutritive value and the proportion of ryegrass in total dry matter during the deferred period, as expected. This was most likely due to shading and death of vegetative tillers. Devantier et al. (2017) reported an increase in the proportion of reproductive stems and seedheads when pastures were 


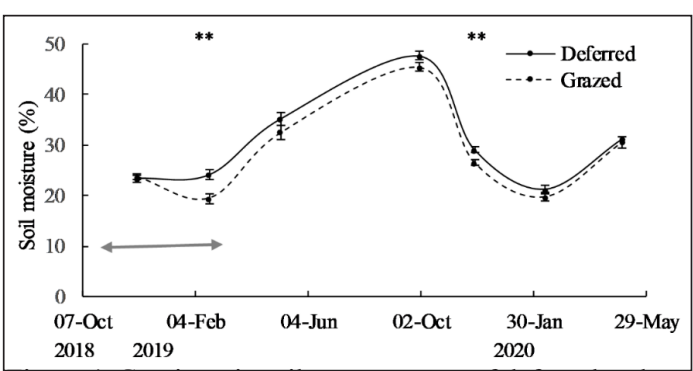

Figure 4 Gravimetric soil water content of deferred and grazed pastures at a depth of $0-7.5 \mathrm{~cm}$ averaged over 6 paddocks on 3 farms in Waikato / Bay of Plenty. Error bars represent the standard error of difference. The arrow denotes the grazing exclusion period in the deferred treatment. Asterisks denote when differences between treatments are significant: ${ }^{* *} \mathrm{P}<0.01$.

deferred while Sanderson and Wedin (1989) found an increase in the NDF, both of which are associated with lower nutritive value. However, there was a large decline in feed quality and a similar proportion of dead matter in both the grazed and deferred pastures. This finding most likely reflects the high temperatures and dry conditions that occurred over the summer of 2018-2019 and associated acceleration of leaf death (Hunt \& Field 1979). Overall, deferred grazing had little impact on the relative species contribution to total dry matter in this study but Garden et al. (2000) found that grazing exclusion may enable some weedy species such as Yorkshire fog to dominate pastures. Using deferred grazing to suppress broadleaf weeds requires investigation given our observations that Californian thistles were suppressed by deferred grazing at Katikati.

\section{Impacts on the soil}

Differences between treatments in average soil temperature during the deferred period were small (albeit statistically significant) and thus would have few biological implications as confirmed by the results of the teabag index. Combining a range of methods such as analyses of enzyme activities (Burns et al. 2013), labile chemical soil properties and microbial community composition (Chaer et al. 2009) might enable detection of differences at a finer scale in future studies.

The soil-water content remained higher in the deferred than grazed pasture for up to 12 months after deferring likely due to shading of the soil surface by senescent plants and lower transpiration rates of mature plants as found by Nie et al. (1997). Increased soil moisture also promotes plant growth (Chen et al. 2007). Rainfall throughout much of 2019 was lower than average and the reservoir of soil water was not replenished, which may explain why the difference between treatments was sustained for months after the deferred period ended. Maximum soil temperatures exceeded $30^{\circ} \mathrm{C}$ in the grazed pastures, the threshold temperature above which clover stolon death can occur when soil moisture is low (Watson et al. 1996).

\section{On-farm application}

Measurements indicated that over half of the vegetation was not consumed in some of the plots (based on preand post-grazing herbage mass data at the end of the deferred period, refer to Table 2). If high levels of dead vegetation remain present in the sward over winter, subsequent spring pasture growth may be compromised (Thompson et al. 2017). The cattle at the Pukemiro and Katikati sites consumed the rank vegetation much more effectively than the ewes at the Kaimai site, where higher post-grazing residuals remained. The rate of quality improvement in the previously deferred pastures depends on the ability of stock to clean-up rank pasture, which will vary from farm to farm; so a hard cleanup graze of deferred pastures at the end of summer/ early autumn with cattle is recommended to remove the poor-quality rank vegetation and facilitate pasture regrowth. It may also be more difficult to remove rank pasture (by grazing or decay) from steep than easy slopes, which may compromise subsequent pasture and livestock productivity (Sheath et al. 1984). Also, care is needed when grazing deferred (and regularly grazed) pastures on steep slopes when there is a risk of runoff and sediment loss.

As a result of this study, the Kaimai and Katikati farmers have greater confidence in deferring $10-15 \%$ of the effective grazing area (i.e. their feed surplus) and in recommending this practice to other farmers. They considered that this practice led to a better match of feed supply and demand during spring and summer on the remaining area of the farm and enabled them to maintain control of their pasture. However, the loss of grazing of the deferred pasture during the deferred period as well as the greater regrowth after the deferred period must also be considered when estimating impacts on farm profitability. Given the prolonged drought, the farmers also considered that deferred pasture could provide a valuable feed source at the end of summer and in early autumn at a time when forage on the farm was scarce.

\section{Conclusions}

In this applied study, deferred grazing had a positive impact on cumulative pasture dry matter production in the year after deferring and reduced the amount of bare ground after deferring, despite summer droughts that likely moderated differences between treatments. Pasture quality was not significantly affected after the deferred period, even on steep slopes. It is recommended that deferred pastures be grazed in autumn with 
cattle rather than sheep to ensure that sufficient dead vegetation is removed to assist in maintaining pasture quality. Further investigation is required to determine if the positive effects of deferring on topsoil temperature, moisture and ground cover reduce runoff, sediment and nutrient losses. Data collected in this study supported farmer observations of the benefits of deferred grazing but modelling is required to quantify the impacts at a farm scale.

\section{ACKNOWLEDGEMENTS}

Thanks to Ministry for Primary Industries Sustainable Farming Fund, the mid-northern North Island Beef and Lamb Farmer Council, Beef + Lamb New Zealand, Ballance Agri-Nutrients, Environment Bay of Plenty, Waikato Regional Council and AgFirst for their funding and in-kind contributions in this project. We also thank Libby North, Tracy Dale, Diane Barton, Caitlyn Dawbin, Kirsty Lyall and Rose Greenfield for their technical assistance and David Hume, David Stevens, Sue Zydenbos and the NZGA reviewers and editor for their helpful comments.

\section{SUPPLEMENTARY MATERIAL}

Additional Online File 1: Figure A1-Rainfall data; Figure A2-Seasonal herbage production; Plate showing photographs from a grazed and deferred paddock https://www.nzgajournal.org.nz/index.php/JoNZG/ article/view/448

\section{REFERENCES}

Burns RG, DeForest JL, Marxsen J, Sinsabaugh RL, Stromberger ME, Wallenstein MD, Weintraub MN, Zoppini A. 2013. Soil enzymes in a changing environment: Current knowledge and future directions. Soil Biology \& Biochemistry 58: 216-234. https://doi.org/10.1016/j.soilbio.2012.11.009

Cardoso EJBN, Vasconcellos RLF, Bini D, Miyauchi MYH, Santos CAd, Alves PRL, Paula AMd, Nakatani AS, Pereira JdM, Nogueira MA. 2013. Soil health: looking for suitable indicators. What should be considered to assess the effects of use and management on soil health? Scientia Agricola 70: 274-289. https://doi.org/10.1590/S010390162013000400009

Cayley JWD, Bird PR. 1996. Techniques for measuring pastures. Department of Agriculture Technical Report Series No. 191. 2nd ed: Victoria, Australia: Department of Agriculture Energy and Minerals, p. 43-45. https://www.evergraze.com.au/wp-content/ uploads/2013/09/Techniques-for-measuringpastures.pdf

Chaer G, Fernandes M, Myrold D, Bottomley P. 2009. Comparative resistance and resilience of soil microbial communities and enzyme activities in adjacent native forest and agricultural soils. Microbial Ecology 58: 414-424. https://doi.org/10.1007/s00248-009-9508-x Chen M-M, Zhu Y-G, Su Y-H, Chen B-D, Fu B-J, Marschner P. 2007. Effects of soil moisture and plant interactions on the soil microbial community structure. European Journal of Soil Biology 43: 3138. https://doi.org/10.1016/j.ejsobi.2006.05.001

Cornforth IS. 1980. Soil and fertilisers: Soil analysis - interpretation. AgLink AST 8. Wellington, New Zealand: New Zealand Ministry of Agriculture and Fisheries.

Cornforth IS, Sinclair AG. 1984. Fertiliser and lime recommendations for pastures and crops in New Zealand. (2nd revised ed.). Wellington, New Zealand: New Zealand Ministry of Agriculture and Fisheries. $66 \mathrm{p}$.

Corson DG, Waghorn GC, Ulyatt MJ, Lee J. 1999. NIRS: Forage analysis and livestock feeding. Proceedings of the New Zealand Grassland Association 61: 127132. https://doi.org/10.33584/jnzg.1999.61.2340

Davidson EA, Janssens IA. 2006. Temperature sensitivity of soil carbon decomposition and feedbacks to climate change. Nature 440: 165-173. https://doi.org/10.1038/nature04514

Devantier BP, Stevens DR, Rennie GM, Tozer KN. 2017. The effect of deferred grazing in spring and early summer pastures on pasture growth rate and feed quality. Proceedings of the New Zealand Society of Animal Production 79: 189-196. https://doi. org/10.33584/jnzg.2017.79.550

Garden DL, Lodge GM, Friend DA, Dowling PM, Orchard BA. 2000. Effects of grazing management on botanical composition of native grass-based pastures in temperate south-east Australia. Australian Journal of Experimental Agriculture 40: 225-245. https://doi. org/10.1071/EA98010

Gordon LJ, Finlayson CM, Falkenmark M. 2010. Managing water in agriculture for food production and other ecosystem services. (Special Issue: Comprehensive Assessment of Water Management in Agriculture). Agricultural Water Management 97: 512-519. https://doi.org/10.1016/j. agwat.2009.03.017

Hunt WF, Field TRO. 1979. Growth characteristics of perennial ryegrass. Proceedings of the New Zealand Grassland Association 40: 104-113. https://doi. org/10.33584/jnzg.1978.40.1518

Kemp DR, Dowling PM. 2000. Towards sustainable temperate perennial pastures. Australian Journal of Experimental Agriculture 40: 125-132. https://doi. org/10.1071/EA98003

Keuskamp JA, Dingemans BJJ, Lehtinen T, Sarneel JM, Hefting MM. 2013a. Tea Bag Index: a novel 
approach to collect uniform decomposition data across ecosystems. Methods in Ecology and Evolution 4: $\quad 1070-1075$. https://doi.org/10.1111/2041210X.12097

L’Huillier PJ, Aislabie DW. 1988. Natural reseeding in perennial ryegrass/white clover dairy pastures. Proceedings of the New Zealand Grassland Association 49: 111-115. https://doi.org/10.33584/ jnzg. 1988.49.1812

Lantinga E, Neuteboom JH, Meijs JAC. 2004. Sward methods. In: Davies A Ed. Herbage intake handbook, 2nd ed, pp. 23-52. Reading, UK: British Grassland Society.

Litherland AJ, Woodward SJR, Stevens D, McDougal DB, Boom CJ, Knight TL, Lambert MG. 2002. Seasonal variations in pasture quality on New Zealand sheep and beef farms. Proceedings of the New Zealand Society of Animal Production 62: 138142.

Matthew C, Chu ACP, Hodgson J, Mackay AD. 1991. Early summer pasture control: what suits the plant? Proceedings of the New Zealand Grassland Association 53: 73-77. https://doi.org/10.33584/ jnzg.1991.53.2008

Nie ZN, Mackay AD, Valentine I, Barker DJ, Hodgson J. 1997. Influence of pastoral fallow on plant root growth and soil physical and chemical characteristics in a hill pasture. Plant and Soil 197: 201-208. https:// doi.org/10.1023/A:1004249613045

Nie ZN, Zollinger RP. 2012. Impact of deferred grazing and fertilizer on plant population density, ground cover and soil moisture of native pastures in steep hill country of southern Australia. Grass and Forage Science 67: 231-242. https://doi.org/10.1111/j.13652494.2011.00838.x

Nie ZN, Zollinger RP, Behrendt R. 2015. Impact of deferred grazing and fertilizer on herbage production, soil seed reserve and nutritive value of native pastures in steep hill country of southern Australia. Grass and Forage Science 70: 394-405. https://doi.org/10.1111/ gfs. 12136

Sanderson MA, Wedin WF. 1989. Phenological stage and herbage quality relationships in temperate grasses and legumes. Agronomy Journal 81: 864869.

Sheath G, Webby R, Pengelly W. (1984). Management of late spring-early summer pasture surpluses in hill country. Proceedings of the New Zealand Grassland Association 45: 199-206. https://doi.org/10.2134/agr onj1989.00021962008100060005x

Sheath GW, Boom RC. 1985. Effects of Nov.-April grazing pressure on hill country Pastures 1 . Pasture structure and net accumulation rates. New Zealand Journal of Experimental Agriculture 13: 317-328. https://doi.org/10.1080/03015521.1985.10426100

Suckling FET. 1959. Pasture management trials on unploughable hill country at te Awa. New Zealand Journal of Agricultural Research 2: 488-543. https:// doi.org/10.1080/00288233.1959.10418033

Thompson BR, Stevens DR, Wall AJ, Moss RA, O'Neill KT, Cox NR. 2017. Winter grazing and dead material effects on early spring pasture production. New Zealand Journal of Agricultural Research 60: 131-139. https://doi.org/10.1080/00288233.2017.12 83633

Waller R, Sale P, Saul G. 2003. Perennial ryegrass survival through summer. Proceedings of the 11th Australian Agronomy Conference, 2-6 February 2003, Unkovich M, O'Leary G, Eds. Geelong, Victoria. http://www.regional.org.au/au/ asa/2003/c/2014/waller.htm

Watson R, Harris S, Bell N, Neville F. 1996. Deferred grazing to enhance white clover content in pastures. Grassland Research and Practice Series 6: 154.

Wider RK, Lang GE. 1982. A critique of the analytical methods used in examining decomposition data obtained from litter bags. Ecology 63: 1636-1642. https://doi.org/10.2307/1940104

Xiao W, Ge X, Zeng L, Huang Z, Lei J, Zhou B, Li M. 2014. Rates of litter decomposition and soil respiration in relation to soil temperature and water in different-aged Pinus massoniana forests in the Three Gorges Reservoir Area, China. PloS one 9: e101890-e101890. https://doi.org/10.1371/journal. pone. 0101890 